SHS Web of Conferences 17, 01024 (2015)

DOI: $10.1051 /$ shsconf $/ 20151701024$

(C) Owned by the authors, published by EDP Sciences, 2015

\title{
The Relationship between Intellectual Capital and Corporate Performance in Chinese Bio-pharmaceutical Industry
}

\author{
Biyun Lv, Dongping Han \\ Department of Economics and Management, Harbin Institute of Technology, Harbin, China
}

\begin{abstract}
With the advent of the knowledge economy, intellectual capital is playing an increasingly important role in the enterprise. Research on the relationship between intellectual capital and corporate performance has important theoretical and practical significance for enterprise to manage and use intellectual capital. Paper selected biopharmaceutical A-share listed companies' data from 2008 2012, and used the method of factor analysis and correlation analysis to verify the relationship between intellectual capital and corporate performance. According to the results, the following conclusion can be made. In bio-pharmaceutical industry, intellectual capital and corporate performance have significant positive correlation, but the degree of correlation is weaker than physical capital. Human capital and structural capital have significant positive correlation with corporate performance. Customer capital and corporate performance are positive related, but not significant. The various components of intellectual capital impact each other, and produce an effect on corporate performance together.
\end{abstract}

Keywords. intellectual capital; corporate performance; factor analysis

\section{Introduction}

In the information age, the level of knowledge and technology has more and more influence on competitiveness. To different types of enterprises, intellectual capital has varying degrees of influence. Bio-pharmaceutical industry is a knowledge-intensive industry. The management of intellectual capital investment has significant impact on its competitive advantage and business performance. But now the impact of intellectual capital and physical capital on corporate performance in this industry have not been very in-depth researched. So it brings the necessity of this study.

\section{Literature review}

\subsection{Relationship between intellectual capital and corporate performance}

Belkaoui (2003) used the least squares method and selected 81 multinational manufacturing and service companies in United States as sample. He chose corporate trademark holdings on behalf of 
the intellectual capital as the independent variables, and chose the relative value of total assets as the dependent variable. Belkaoui verified the relationship between intellectual capital and corporate performance, concluding: intellectual capital has a significant positive role in promoting on firm performance, and this effect is persistent. ${ }^{[1]}$

Mavridis and Kyrmizoglou (2004 and 2005) selected banks in Japanese and Greek as sample. They used linear regression and comparison analysis method, and chose intellectual capital and physical capital as independent variables, and chose corporate value added as the dependent variable. Mavridis and Kyrmizoglou verified the relationship between intellectual capital and corporate performance, concluding: intellectual capital and physical capital are significantly correlated with corporate performance, and the former is more relevant than the latter. ${ }^{[2]}$

\subsection{Relationship between the composition of intellectual capital and corporate performance}

Firer and Williams (2003) divided the intellectual capital into two parts: human capital and structural capital and selected 65 knowledge-based listed companies in South Africa as sample, choosing intellectual capital appreciation factor as independent variable. Firer and Williams verified the relationship between intellectual capital and corporate performance, concluding: physical capital and structural capital have a significant role in promoting corporate performance, but human capital's effect on corporate performance is not significant. ${ }^{[3]}$

Zhang and Han (2011) selected pert of manufacturing, information technology and real estate industry A-share listed companies' data from 2002 to 2008 as sample to do comparative study, choosing ROE as the dependent variable. Zhang and Han concluded: intellectual capital have a positive effect on corporate performance in the three sectors, but in addition to the information technology industry. The impact of human capital and relational capital on corporate performance is not significant. ${ }^{[4]}$

Abdullah et al (2012) divided intellectual capital into human capital, structural capital, relational capital and spiritual capital, and obtained 144 listed companies' data in Malaysia by questionnaire, using Pearson correlation analysis to verify the relationship between intellectual capital and corporate performance, concluding: human capital, structural capital, relational capital and spiritual capital all have a significant role in promoting corporate performance, and relational capital has the maximum affect. ${ }^{[5]}$

Existing research has focused on the relationship between intellectual capital and corporate performance. Following are several shortcomings about these studies:

(1) The comparability of research findings was not high. Due to scholars' different view of the components of intellectual capital and different aspects of verification, their conclusions lack of comparability.

(2) Selection of the dependent variable was too extensive. The vast previous studies just chose a small number of indicators, such as ROE, as the dependent variable. These indicators could not fully reflect corporate performance, thereby affected the accuracy of the findings.

\section{Research design}

\subsection{The overall train of thought}

To solve the above problems, this paper will first divide intellectual capital into human capital, structural capital and customer capital, with the intellectual capital gain coefficient as independent variable, using factor analysis to obtain corporate performance, profitability, asset management level, solvency and follow-up development capacity index as dependent variables. Then, to prove the correlation between the independent variables and the dependent variable, as well as the correlation between the various parts of the dependent variable, the Pearson analysis method will 
be used. Finally, the partial correlation analysis will be used to determine the role of intellectual capital on business performance.

\subsection{Research hypothesis}

According to resource-based theory, heterogeneous resource is a source of competitive advantage. It is difficult to be imitated by other enterprises. Intellectual capital is a kind of enterprise heterogeneous resource. So following hypothesizes can be made:

Hypothesis 1: intellectual capital and corporate performance are significantly positive correlated.

Hypothesis 2: human capital and corporate performance are significantly positive correlated.

Hypothesis 3: structure capital and corporate performance are significantly positive correlated.

Hypothesis 4: customer capital and corporate performance are significantly positive correlated.

Hypothesis 5: intellectual capital parts relate to each other, and have mutual impact on corporate performance.

\subsection{Data and sample}

This paper uses Chinese A-share listed bio-pharmaceutical companies' data from 2008 2012. These companies list on the Shenzhen Stock Exchange and Shanghai Stock Exchange. Incomplete and abnormal data was deleted. At last, there remain 335 samples. Data is from the RESSET databases and the CNINFO website.

\subsection{Variable selection}

\subsubsection{Dependent variable selection}

According to The Ministry of Finance, corporate performance is defined as an enterprise operating efficiency and operator performance during a certain business. Corporate efficiency is mainly in terms of profitability, asset management level, solvency and subsequent development capacity. Operator achievement is primarily reflected by the contribution made by operators during the operation and management of the enterprise to business process, growth and development. Thus, this paper selected 21 indicators which currently are more commonly used by scholars, and divided them into five areas to measure corporate performance. These five areas are represented by $Z 、 Z_{1} 、 Z_{2} 、 Z_{3} 、 Z_{4}$. SPSS was used as analysis tool.

\subsubsection{Independent variable selection}

There are many ways to measure intellectual capital. But the Value Added Intellectual Capital (VAIC) has high recognition, simple calculation, and is data readily available and comparable. Therefore, the paper uses the VAIC method.

The VAIC divides intellectual capital into human capital and structural capital, but the paper argues that intellectual capital should be divided into human capital (HC), structural capital (SC) and customer capital (RC). So, VAIC formula is modified to: human capital value coefficient $(\mathrm{HCE})+$ structural capital value coefficient (SCE) + customer capital value coefficient (RCE). The independent variable list is as follows: 
Table 1. Independent variable

\begin{tabular}{llll}
\hline Independent variable & Symbolic & $\begin{array}{l}\text { Computation } \\
\text { formula }\end{array}$ & Notes \\
\hline Value added intellectual capital & VAIC & HCE+SCE+RCE & CE represents physical capital, \\
Human capital value coefficient & HCE & VA/HC & HC represents human capital, \\
Structural capital value coefficient & SCE & VA/SC & SC represents structural capital, \\
Customer capital value coefficient & RCE & VA/RC & RC represents customer capital, \\
Physical capital value coefficient & CEE & VA/CE & $\begin{array}{l}\text { PBT represents physical capital, } \\
\text { Enterprise value added }\end{array}$ \\
& VA & PBT+SS+FC & SS represents staff salary, \\
& & & FC represents financial cost. \\
\hline
\end{tabular}

\subsection{Research model}

Correlation analysis model:

$$
\left\{\begin{array}{l}
\mathrm{Z}_{\mathrm{i}}=r_{i 1} V A I C \\
\mathrm{Z}_{\mathrm{i}}=r_{i 2} H C E \\
\mathrm{Z}_{\mathrm{i}}=r_{i 3} S C E \\
\mathrm{Z}_{\mathrm{i}}=r_{i 4} R C E \\
\mathrm{Z}_{\mathrm{i}}=r_{i 5} C E E
\end{array}\right.
$$

Definition of formula values: $\mathrm{i}=0,1,2,3,4 ; \mathrm{r}_{\mathrm{i} 1}, \mathrm{r}_{\mathrm{i} 2}, \mathrm{r}_{\mathrm{i} 3}, \mathrm{r}_{\mathrm{i} 4}, \mathrm{r}_{\mathrm{i} 5}$ represent correlation coefficients between $Z_{\mathrm{i}}$ and VAIC, HCE, SCE, RCE, CEE.

\subsection{Results and analysis}

\subsubsection{Correlation Analysis}

SPSS17.0 provides a function about correlation analysis between two variables. This function was used to analyze correlation between independent variable and dependent variable. The table 2 and 3 are the results.

Table 2. Correlations between intellectual capital and corporate performance

\begin{tabular}{lllllll}
\hline & & $\mathrm{Z}_{1}$ & $\mathrm{Z}_{2}$ & $\mathrm{Z}_{3}$ & $\mathrm{Z}_{4}$ & $\mathrm{Z}$ \\
\hline \multirow{2}{*}{$\mathrm{VAIP}$} & Pearson Correlation & $.732^{* * *}$ & $.576^{* * *}$ & .079 & $-.131^{* *}$ & $.097^{*}$ \\
& Sig. (2-tailed) & .000 & .000 & .148 & .016 & .077 \\
$\mathrm{HCE}$ & Pearson Correlation & $.767^{* * *}$ & $.639^{* * *}$ & .080 & $-.117^{* *}$ & $.100^{*}$ \\
& Sig. (2-tailed) & $.000^{* * *}$ & $.000^{* * *}$ & .146 & .033 & .067 \\
$\mathrm{SCE}$ & Pearson Correlation & $.782^{*}$ & $.199^{* *}$ & .084 & .044 & $.094^{*}$ \\
& Sig. (2-tailed) & .000 & .000 & .124 & .427 & .086 \\
\multirow{2}{*}{$\mathrm{RCE}$} & Pearson Correlation & $.484^{* * *}$ & $.503^{* * *}$ & .054 & $-.162^{* * *}$ & .068 \\
& Sig. (2-tailed) & .000 & .000 & .320 & .003 & .214 \\
$\mathrm{C}$ CEE & Pearson Correlation & $.469^{* * *}$ & -.074 & $.157^{* * *}$ & $.118^{* *}$ & $.164^{* * *}$ \\
& Sig. (2-tailed) & .000 & .178 & .004 & .031 & .003
\end{tabular}

Note : ${ }^{* * *}$ : Correlation is significant at the 0.01 level (2-tailed); : Correlation is significant at the 0.05 level (2-tailed); ${ }^{*}$ : Correlation is significant at the 0.1 level (2-tailed).

The above table shows that intellectual capital, human capital and structural capital have significantly positive correlation with corporate performance. Customer capital and corporate performance are related but not significant. Physical capital and corporate performance are related, 
representing more significant and more relevant than the relationship between intellectual capital and corporate performance. Intellectual capital, human capital, structural capital and customer capital have significantly positive correlation with profitability and solvency. Compared with physical capital, they have more significant and stronger relationship with the solvency. Intellectual capital, human capital, structural capital and customer capital have a positive correlation with the subsequent development capacity, but not significant. Intellectual capital, human capital and customer capital are significantly negatively correlated with asset management level. Structural capital is positively correlated with asset management level, but not significantly. Therefore, hypothesis 1, 2 and 3 are all verified. But hypothesis 4 is rejected.

Table 3. Correlations between various components of intellectual capital

\begin{tabular}{lllll}
\hline & & HCE & SCE & RCE \\
\hline HCE & Pearson Correlation & 1 & $.719^{* * *}$ & $.595^{* * *}$ \\
& Sig. (2-tailed) & & .000 & .000 \\
SCE & Pearson Correlation & & 1 & $.367^{* * *}$ \\
& Sig. (2-tailed) & & & .000 \\
\multirow{2}{*}{ RCE } & Pearson Correlation & & 1 \\
& Sig. (2-tailed) & & \\
\hline
\end{tabular}

Note : ${ }^{* * *}$ : Correlation is significant at the 0.01 level (2-tailed); $:$ Correlation is significant at the 0.05 level (2-tailed); ${ }^{*}$ : Correlation is significant at the 0.1 level (2-tailed).

As can be seen from the table of correlation between the independent variables, independent variables are significant correlated with each other. Thus, the various components of intellectual capital are interrelated and interdependent. Although during the Pearson correlation analysis, the customer capital is not significant related with corporate performance, it does not mean that the customer capital does not affect the corporate performance. As can be seen from the table 3, customer capital can significantly affect other capital, thus affecting corporate performance. So, when companies manage intellectual capital, they should take the relationship between the various parts of intellectual capital into account in order to avoid a loss and do not reduce management efficiency.

\subsubsection{Partial correlation analysis}

Partial correlation analysis provides by SPSS17.0 is used to analyze correlation between independent variable and dependent variable. The table 4,5 and 6 are the results.

Table 4. Correlations after controlling human capital

\begin{tabular}{lllll}
\hline Control Variables & & & $\mathbf{Z}$ & $\mathbf{Z}$ \\
\hline \multirow{3}{*}{ HCE } & \multirow{2}{*}{ SCE } & Pearson Correlation & .032 & .094 \\
& & Sig. (2-tailed) & .562 & .086 \\
& \multirow{2}{*}{ RCE } & Pearson Correlation & .011 & .068 \\
& & Sig. (2-tailed) & .846 & .214 \\
\hline
\end{tabular}

Table 5. Correlations after controlling structural capital

\begin{tabular}{lllll}
\hline Control Variables & & & $\mathbf{Z}$ & $\mathbf{Z}$ \\
\hline \multirow{4}{*}{ SCE } & \multirow{2}{*}{ HCE } & Pearson Correlation & .036 & .100 \\
& & Sig. (2-tailed) & .509 & .067 \\
& \multirow{2}{*}{ RCE } & Pearson Correlation & .036 & .068 \\
& & Sig. (2-tailed) & .509 & .214 \\
\hline
\end{tabular}


Table 6. Correlations after controlling customer capital

\begin{tabular}{lllll}
\hline Control Variables & & & $\mathbf{Z}$ & $\mathbf{Z}$ \\
\hline \multirow{4}{*}{ RCE } & HCE & Pearson Correlation & .074 & .100 \\
& & Sig. (2-tailed) & .175 & .067 \\
& SCE & Pearson Correlation & .074 & .094 \\
& & Sig. (2-tailed) & .175 & .086 \\
\hline
\end{tabular}

The first column in table 4, 5 and 6 is the partial correlation coefficients obtained by the partial correlation. The second column is the correlation obtained from the Pearson correlation analysis. Summarizing the results of the partial correlation analysis, we found that when control one component of the intellectual capital, the correlation coefficients as well as the significance between the other components and corporate performance will reduce, and the impact on corporate performance will be weaker. It means that the various parts of intellectual capital are not independently affect corporate performance, but have mechanisms to work together on corporate performance between them. Therefore, hypothesis 5 is verified.

\section{Conclusions}

This article divides intellectual capital into three parts: human capital, structural capital and customer capital. Then it uses Pearson correlation analysis and partial correlation analysis to verify the relationship between intellectual capital and corporate performance, and reaches the following conclusions:

(1) Intellectual capital, human capital and structural capital are significantly and positively correlated with corporate performance. Customer capital is positively related with corporate performance, but not significant. The four correlation coefficients are less significantly than physical capital. It means that although bio-pharmaceutical industry is a knowledge-intensive industry, it still mainly relies on physical capital to pull at this stage. The industry is insufficient for the use of intellectual capital, and its innovation capacity is not enough.

(2) Intellectual capital, human capital, structural capital and customer capital have significant positive correlation to profitability and solvency. The four significant correlation coefficients are greater than physical capital. Human capital, structural capital and customer capital are positive correlated with the subsequent development capability, but not significant. Human capital and customer capital are significantly negatively correlated with asset management. Structural capital is positively correlated with asset management level, but not significantly. And the physical capital is significantly positively correlated with subsequent development capability and asset management level. It is visible that although the impact of intellectual capital on the overall performance of the enterprise is less than physical capital, the impact of intellectual capital and physical capital to the different aspects of corporate performance is different.

(3) The parts of intellectual capital impact each other, and produce an effect on corporate performance together. According to the results of the partial correlation analysis, when controlling one of the intellectual capital variables, the correlation coefficients between other variables with corporate performance will decrease, and the significance will reduce. It means that the various parts of intellectual capital are not independent in affecting corporate performance, but have mechanisms to work together on corporate performance between them. Therefore, when companies use and manage the intellectual capital to improve corporate performance, they should take into account the mechanism of action between the various components of intellectual capital for the corporate performance impact, with a reasonable collocation of human capital, structural capital and customer capital. 


\section{References}

1. Riahi-Belkaoui. Intellectual Capital and Firm Performance of Multinational Firms [J]. Journal of Intellectual Capital. 2003, 4(2): 215-226.

2. Mavridis D G, Kyrmizoglou P. Intellectual Capital Performance Drivers in the Greek Banking Sector [J]. Management Research New, 2005, 28(5).

3. Steven Firer, S. Mitchell Williams. Intellectual Capital and Traditional Measures of Corporate Performance [J]. Journal of Intellectual Capital, 2003; 3

4. Zhang Z.Y., Han H.D. . A Comparative Study of the relationship between intellectual capital and business performance among industries [J]. Technology Progress and Policy. 2011, 28(16): 47-51.

5. Dewi Fariha Abdullah, Saudah Sofian. The Relationship between Intellectual Capital and Corporate Performance [J]. ELSEVIER SCIENCE BV: AMSTERDAM. 2012: 537-541.

6. Rudez, H.N. and T. Mihalic. Intellectual capital in the hotel industry: A case study from Slovenia [J]. Science direct. 2007, (26): 188-199.

7. Sydler, R.S. Haefliger and R. Pruksa. Measuring intellectual capital with financial figures can we predict firm profitability [J]. European Management Journal. 2013: 1-16.

8. Cao Y., Chen X.H., Ma Y.R. The relationship between intellectual capital and coorperate performance based on life cycle [J]. Systems Engineering Theory and Practice. 2010, 30(4): 577-586.

9. Wang L., Sun H.J. Impact of intellectual capital on the performance of listed companies - use bio-medicine, textile and apparel industry as example [J]. Accounting Monthly. 2012, (30): 33-37.

10. Fan L.B., Ding T., Yuan X. Research on the relationship between intellectual capital and corporate performance - Empirical Analysis Based on Panel Data Model. Hainan University (Humanities and Social Sciences). 2012, 30(4): 106-112. 